溶㶡に酸添加の条件下で重合を行ならと非常に透過率の 高い重合体溶液を得, これより紡糸した䋊維は加水分解 のない白度のすぐれた瀻維を得る。

付 記：本研究の発表を許可された会社当局に感煀する。

$$
\text { 文献 }
$$

1）吉田正俊, 谷山雅一：未発表

2) 吉田正俊：未発表 $\left(\mathrm{AN}\right.$ を $\mathrm{ZnCl}_{2}$ 水溶液中で重合 禁止剂 $\left(\mathrm{Cu}^{++}\right.$イオン)の存在下で APS 存在下 $60^{\circ} \mathrm{C}$ で酸化すると $300 \sim 400 \mathrm{~m} \mu$ の吸収を有する有色物
を得る)

3) H.W. Melville: Trans. Faraday. Soc., 50, 73 (1954)

4) H. W. Melville: J. Soc. Dye. Col., 65, 703(1949)

5) J. Weiss, D. Porret: Nature, 139, 1019(1937)

6) J. W. L. Fordam: J. Polymer Sci., 39, 321(1959)

7) 吉田正俊：末発表

8) 吉田正俊, 谷山雅一：高化, 19, 633(1962)

9) 岡村誠三：C. A., 54, 14771(1960)

10) 本山卓彦, 真野隆司：高分子展望第 14 集, 70(1959)

\title{
Photo-polymerization of Acrylonitrile in Zinc Chloride Aqueous Solution.
}

\section{On Sensitizer in Ultraviolet Induced Photo-polymerization}

\section{By Masatoshi Yoshida* and Masakazu Taniyama*}

In the case of producing the spinning solution which are prepared by solution polymerization of acrylonitrile in zinc chloride aqueous solution, it is necessary for the solution to have an excellent transparency, in order to spinning fiber with high whiteness.

It has been known that, for producing its transparency, the following conditions are required :

The polymerization must be done (1) at the lower temperature, (2) at the state of the lower $\mathrm{pH}$, namely adding acids to the solution, and (3) in the existence of smaller amounts of the catalyser (or sensitizer).

It was found that, as an excellent sensitizer, $\alpha, \alpha^{\prime}$-azobisisobutylonitrile, benzoin, uranyl nitrate, hydrogen peroxide and ammonium persulfate, etc. were effective, on the other hand benzil, benzophenone, stannous chloride and cerium nitrate, etc. were not so effective.

Rate of polymerization depends upon the concentration of monomer and sensitizer as following ;

sensitizer
uranyl nitrate
$\alpha \alpha^{\prime}$-azobisisobutylonitrile
benzoin
ammonium persulphate
hydrogen peroxide

$$
\begin{gathered}
\text { rate of polymerization } \\
{[M]^{2} \times\left([C]^{0.28}+\alpha\right)} \\
{[M] \times\left([C]^{0.5}+\alpha^{\prime}\right)} \\
{[M] \times\left([C]^{0.58}+\alpha^{\prime \prime}\right)} \\
{[M] \times\left([C]^{0.5}+\alpha^{\prime \prime \prime}\right)} \\
{[M] \times\left([C]^{0.4}+\beta\right)}
\end{gathered}
$$

: where $C$ is the concentration of sensitizer.

$\alpha, \alpha^{\prime}, \alpha^{\prime \prime}, \alpha^{\prime \prime \prime}$ and $\beta$ represent constants.

\section{第 2 報 紫外線重合における増感剤の特性について \\ (1961 年 10 月 16 日受理) \\ 吉田正俊**. 谷山雅一**}

\begin{abstract}
要旨 第 1 報において光重合と熱重合の効果の差につき, 重合体溶液の透過率の点から検尉し, また

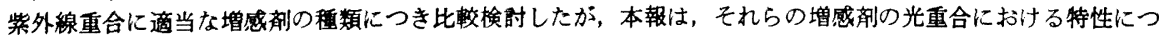
き研究を行なった。まず塩化亜鉛水溶液中に㧍けるアクリロニトリル（以下 AN と略記す）の光重合速度 $\left(R_{p}\right)$
\end{abstract}

\footnotetext{
* Research Department of Toho Rayon Co. Ltd. (Kitajima, Itano, Tokushima)
}

** 東邦レーヨン株式会社研究所(徳岛県板野郡北白町高戻川上 8) 
は光の强度 $(I)$ と次の関係にあることを見出した。

増感䬉: $\alpha \alpha^{\prime}$ azobisisobutylonitrile (ABIN) $R_{p} \propto I^{0.5}$

" : ammonium persulfate (APS) $\quad R_{p} \propto I^{0.5}$

": : hydrogen peroxide (HPO) $\quad R_{p} \propto I^{0.7}$

増感郕の吸光俰数 $(\alpha)$ については次のごとくである。今もし過酸化水素の場合 $\alpha=1$ とすれば, ABIN では $\alpha=7.82$, Benzoin(BZI) では $\alpha=12.5$ である。重合速度は， $\alpha$, 增感凧渡度 (c), セル゙の!厚さ (d) および Intensity exponent $(n)$ と次の関係にある。一般に $R_{p}=A I^{n}$ および $I_{0} / I=10^{\alpha \cdot c \cdot d ~ こ こ て ゙ ~} A$ はモノマー 浱度一定の埸合は定数。 $I_{0}$ は入射光の強度である。したがって両式より

$$
\log R_{p}=\log A I_{0} n-\alpha \cdot c \cdot d \cdot n
$$

著者らは，上式が成立することを确かめた。ここで $(\alpha \cdot c \cdot n)$ の矰の小さい増感郕が，光源より遠い位置の被 重合液でも，重合速度が衰えないといらことがいえる。下記にその測定值を示すごとく HPO がいちばんそ の値が小さく，したがって重合の均一性が良いことを見出した。

$$
\begin{aligned}
\text { HPO: } & \alpha \cdot c \cdot n=0.77 \\
\text { ABIN: } & \alpha \cdot c \cdot n=2.25 \\
\text { BZI : } & \alpha \cdot c \cdot n=3.78
\end{aligned}
$$

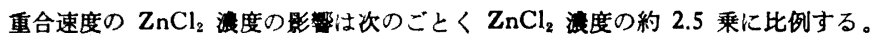
APS: $\quad R_{p}=k[\mathrm{AN}]\left(\alpha^{\prime}+[\mathrm{APS}]^{0.5}\right)\left[\mathrm{ZnCl}_{2}\right]^{2.5}$

$\mathrm{HPO}: \quad R_{p}=k[\mathrm{AN}]\left(\beta^{\prime}+[\mathrm{HPO}]^{0.5}\right)\left[\mathrm{ZnCl}_{2}\right]^{2.3}$

ここで $\alpha^{\prime}$ および $\beta^{\prime}$ は定数である。また分子量の逆数は $\mathrm{ZnCl}_{2}$ 湻度の 2 乗に比例する。

\section{1. 緒 言}

光重合が実際の工業的規模において用いられない理由 は重合装圆に工夫がいるといら点であり，それは光の透 過性に問題があり，被照射体の厚みが増すに従い光強度 が低下し，したがって重合の不均一性が問題になること によっている。この点につき検討を加えてみた。一方 $\mathrm{ZnCl}_{2}$ 水溶液中の $\mathrm{AN}$ の重合は非常に速く, 熱重合の 場合にかぎらず, 光重合の場合でも非常に速いわけであ るが，その点につき $\mathrm{ZnCl}_{2}$ が どのような形で寄与して いるかにつき検討を加えてみた。それらの結果につき以 下に示す。

\section{2. 実酫}

\section{1 光の强さ（光源よりの距離）の影零について} 実験装置は前報1) と大体同梯で光源はマッダ超高圧水 銀灯 (SHL-100 UV) をガラスシリンダーにて保護し, かつ空冷しつつ $20^{\circ} \mathrm{C}$ 恒温槽に入れ, 光源よりの距離を 代えた位置に $11 \mathrm{~mm} \phi$ のガラス管に被重合液を封入し, 光を照射し，一定時間ごとの重合率を測定し，各光源よ りの距離に扔ける重合速度 $\left(R_{p}\right)$ を測定した。もし光源 が点光源であるなら, 光源よりの距離, $(l)$ の位置の光の 強さ $(I)$ は一般に次の関倸にある。

$$
I \propto I_{0} \times 1 / l^{2} \quad\left(I_{0} \text { は } l=0 \text { の光の強度 }\right)
$$

$R_{p}$ とlの間の関係を求めるため, 次の条件で重合を

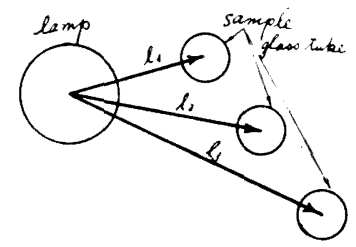

Fig. 1. Effect of distance from light source.
行なった。

Polymerization condition

Temperature of polymerization: $20^{\circ} \mathrm{C}$

Composition of polymerized solution

$60 \% \mathrm{ZnCl}_{2}$ aq. solution: $85.5 \mathrm{~g}$

Iso propylalcohol $: 4.5 \mathrm{~g}$

Acrylonitrile : $10.0 \mathrm{~g}$

Sensitizer ABIN : $100 \mathrm{mg}$ ( $1 \%$ vs. monomer) or BZI : $70 \mathrm{mg}(0.7 \%$ vs. monomer $)$ or HPO : $10 \mathrm{mg}(0.1 \%$ vs. monomer $)$ or APS : $30 \mathrm{mg}(0.3 \%$ vs. monomer $)$

光源よりの距離を $5.3,8.1,10.3,14.9,20.0,30.2 \mathrm{~cm}$ と変更した。その場合のそれぞれの時間に対する重合率 は Fig. 2-a の(1), (2), (3), (4) にそれぞれの増感阂につい て図示した。以上の結果から重合速度定数を算出し，そ れと光源よりの距離との関係を Fig. 2-b に示した（た だし速度定数は重合速度がモノマー濃度の 1 乗に比例す ることを見出したのでそれに基き計算して出した)。

これより次の結果を得る。

$$
\begin{aligned}
\text { ABIN : } & R_{p} \propto[I]^{0.5}[M] \\
\text { APS : } & R_{p} \propto[I]^{0.5}[M] \\
\text { HPO : } & R_{p} \propto[I]^{0.7}[M] \\
& \text { ただし }[M]: \text { モノマー濃度 }
\end{aligned}
$$

BZI に関してはデータよりの計算の精度上, 難があるの で省略した。

次に光源よりの距離と分子量の関倸は Fig. 2-c に示 すごとくである。光強度の低下とともに分子量は増大す ることを見出した。

\section{2 光強度の測定法}

2.1 の実験で $I$ と $l$ との間に前述の式がなりたつと して計算した。しかし，これは光源が点光源である場合 で，実際はそのような関釈があるかどうか不明なのでこ 


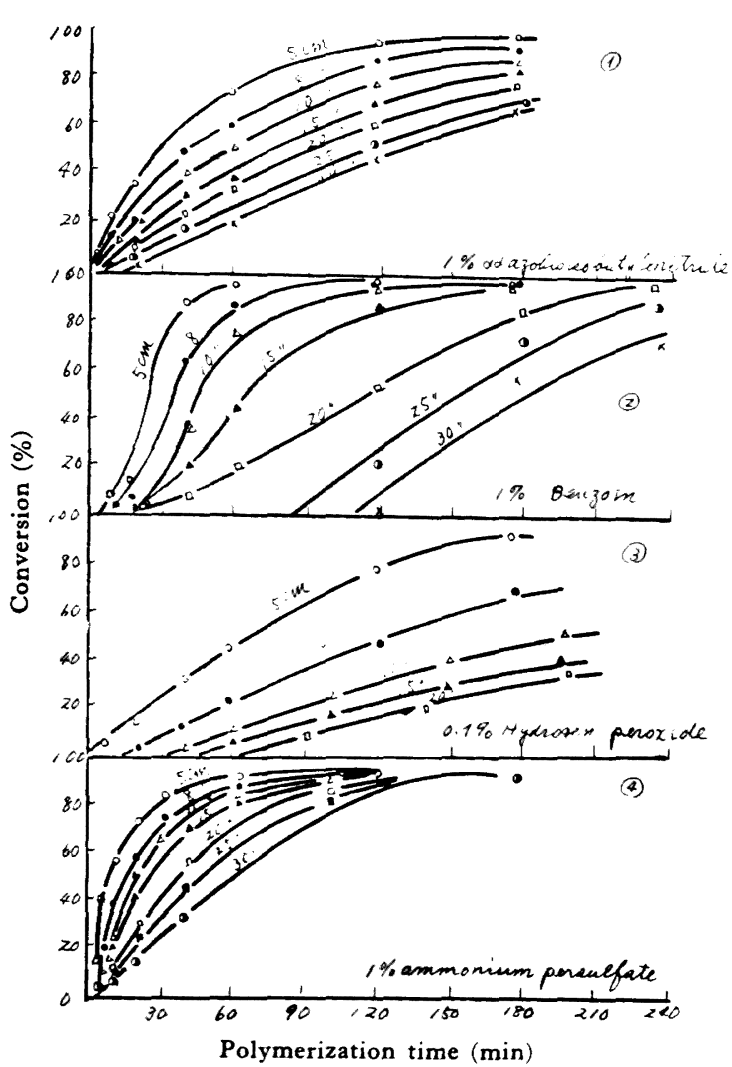

Fig. 2-a. Rate of polymerization vs. distance from light source.

の点を検郡した。化学的に光强度を測定する方法として Uranyl oxalate actinometer を用いるが,これは光強度 の鉴囲があまり大きくとれないことと，正確さがない久 点があるので, Potassium ferrioxalate 法2) $\left(\mathrm{K}_{3}\left[\mathrm{Fe}\left(\mathrm{C}_{2}\right.\right.\right.$. $\left.\left.\left.\mathrm{O}_{4}\right)_{8}\right] 3 \mathrm{H}_{2} \mathrm{O}\right)$ で行なうことにした。

Table 1 に示すごとくPotassium ferrioxalate 水溶 液に光を照射すると， $\mathrm{Fe}^{+++}$が $\mathrm{Fe}^{++}$になり，これに $1: 10$ phenanthroline $0.1 \%$ solution を加えると赤かつ 色になり，これは $5100 \AA$ の波長の光学密度を測定する ことによって $\mathrm{Fe}^{++}$量を測定し5る(この場合 $5100 \AA$ の波長には $\mathrm{Fe}^{++}$の量のみが影響し他のものの影響はな い。そしてその分解量は光強度 $(I)$ のみに比例する。

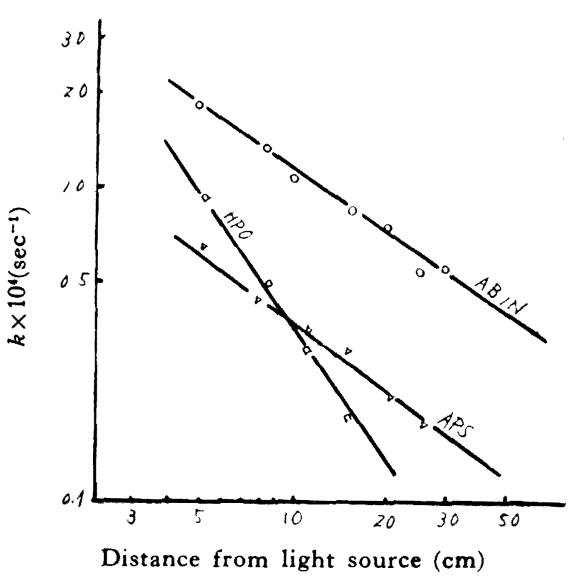

Fig. 2-b. Velocity costant vs. distance from light source.

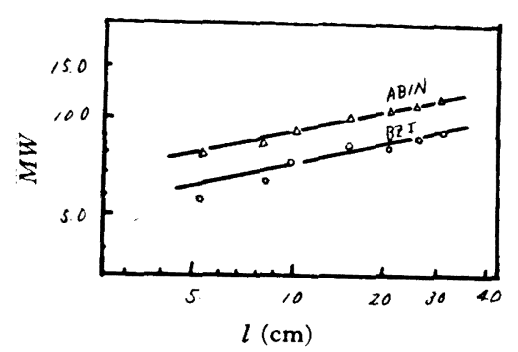

Fig. 2-c. Molecular weight vs. distance from light source.

分解して生じた $\mathrm{Fe}^{++}$量と光学密度との関係すなわち検 定曲線を Fig. 3 の左側に示す。すなわち $\mathrm{Fe}^{++}$量と光 学密度との間に直線関係がなりたつ。またこれより光源 からの距離と分解量 $\left(\mathrm{Fe}^{+++}\right.$あるいは生成 $\mathrm{Fe}^{++}$量) との 間の関係を求めると, Fig. 3 の右側のごとき関係がなり たち，したがって大体光源よりの距離の $1 / 2$ 乗の逆数に 光強度が比例するという仮定は正しいことがわかった。

2.3 セルの原みと光強度の低下案について

一般に物犋が光を照射されたときに入射光強度 $\left(I_{0}\right)$ と 透過光強度 $(I)$ の間には次の関係がある。

$$
\log I_{0} / I=\alpha \cdot c \cdot d
$$

Table 1. Potassium ferrioxalate method.

$$
\begin{aligned}
& 2\left[\mathrm{Fe}\left(\mathrm{C}_{2} \mathrm{O}_{4}\right)_{3}\right]^{3-} \stackrel{h_{\nu}}{\longrightarrow} 2 \mathrm{Fe}\left(\mathrm{C}_{2} \mathrm{O}_{4}\right)_{2}+3\left[\mathrm{C}_{2} \mathrm{O}_{4}\right]^{2-}+2 \mathrm{CO}_{2}
\end{aligned}
$$

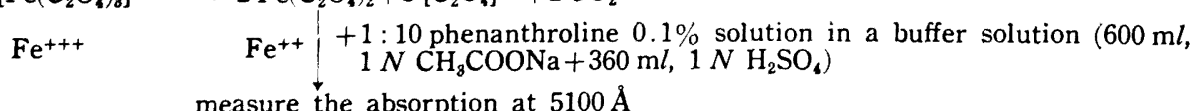




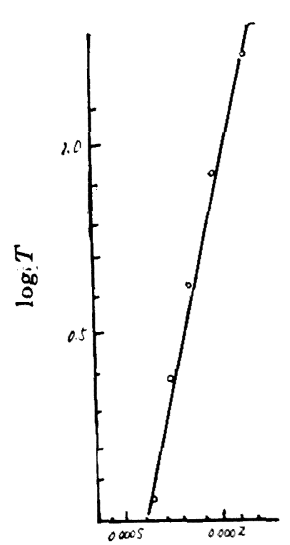

$\mathrm{Fe}^{++}(\mathrm{mol} / \mathrm{l})$

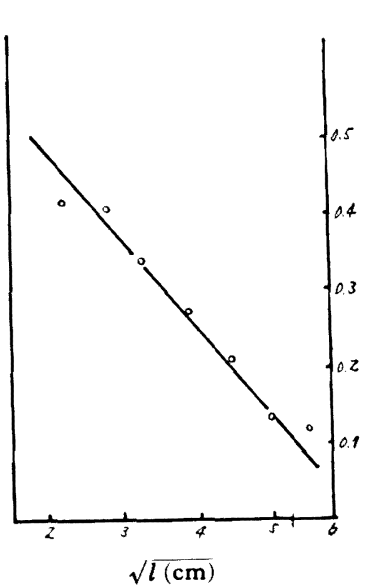

Fig. 3. Decomposition concentration of $\mathrm{Fe}^{+++}$vs. optial density and distance from light source $(l)$.

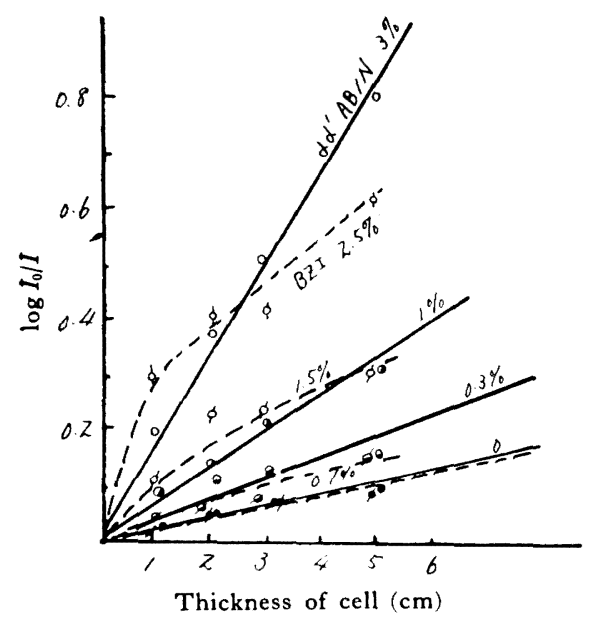

Fig. 4. $\log \left(I_{0} / I\right)$ vs. thickness of cell.

ここで $\alpha$ : 吸光倸数, $c$ : 増感片濃度, $d:$ 七ルの厚さ 今この関係を用いて各種の増感剤の $\alpha$ を求めてみた。 寸なわち Fig. 4 に AN に対して各重量\% の ABIN と $\mathrm{BZI}$ を $58 \% \mathrm{ZnCl}_{2}$ 水溶液中に, $\mathrm{AN}$ を溶剂に対して 10 重量\% とともに溶解し, セルの厚みを変えて測定し た。 $I_{0} / I$ の值とセルの厚み $(d)$ の関係を図示した。 ABIN の場合はその関倸はほぼ直線になり, BZI の場合 はややわん曲したが理由は不明である。いずれにしても 光強度の低下は主として増感成の量と七ルの厚さに影響 され, $\mathrm{ZnCl}_{2}$ 水溶液や $\mathrm{AN}$ の影響は小さい。ここで用 いた光の波長はフィルターで $360 \pm 20 \mathrm{~m} \mu$ の選択波長 を用いた。

\section{4 增感剛の五と光強度の低下率について} セルの厚さを一定 $(3 \mathrm{~cm})$ にし, 增感剂の䟴度と光強

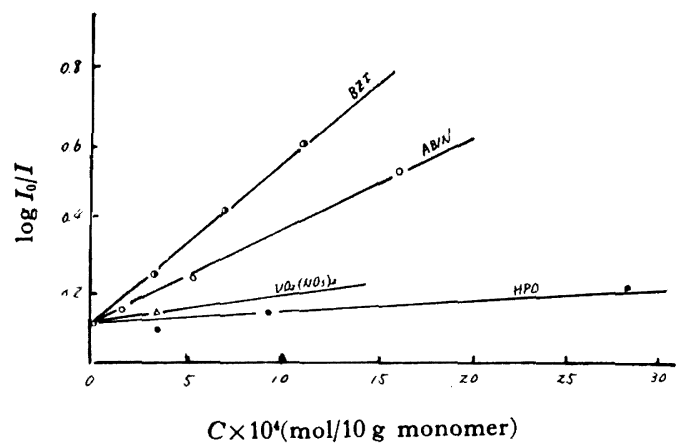

Fig. 5. Lowering rate of light intensity vs. concentration of sensitizer.

度の低下率の関係を図示すると Fig. 5 のごとくなり, この直線の傾斜が吸光係数 $(\alpha)$ と比例する数值を表わし ているが, 今簡単のために HPO の $\alpha$ を 1 とすると他 のものは次のごとくなる。

$$
\left.\begin{array}{rl}
\text { HPO } & \alpha=1.0 \\
\text { ABIN } & \alpha=7.82 \\
\text { BZI } & \alpha=12.5
\end{array}\right\}
$$

\section{5 セルの原みと重合速度の関係}

Fig. 6 に示すごとき装置で, 四角のガラス重合容器を 光源に向かって一列に並へ，ランプの近くから，1，2,3， $4,5,6$ と符号をつける。光源からガラスセルの中央の位

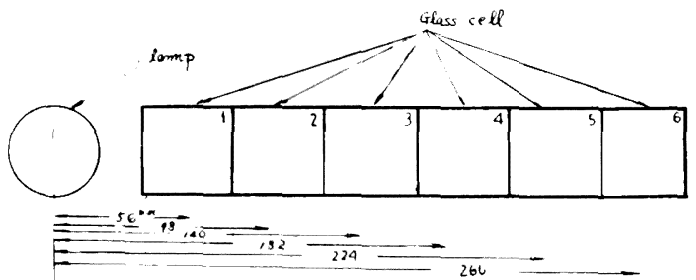

Fig. 6. Apparatus of photo-polymerization for studying the effect of cell thickness.

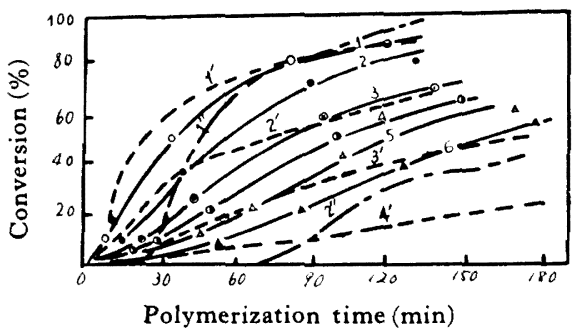

(No. on curve is number of cells)

$$
\begin{array}{ll}
- & \text { HPO } \\
\hline--: & \text { ABIN } \\
\cdots \cdot-\cdot: & \text { BZI }
\end{array}
$$

Fig. 7. Rate of polymerization vs. the position of the cell. 


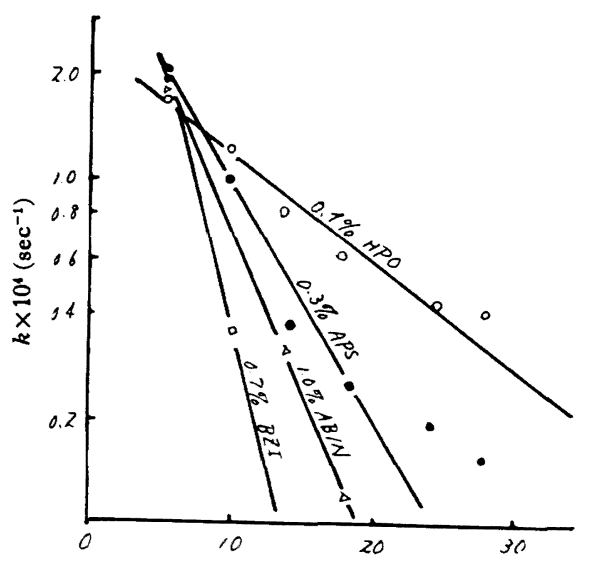

Thickness of cell $(\mathrm{cm})$

Eig. 8. Velocity constant of polymerization vs. thickness of cell.

置までの距離は Fig. 6 に示す。この条件のもとで各種 増感昘の重合時間と重合率の 1 例を Fig. 7 に示す。以 上の結果から各重合速度定数を定め, それとセルの厚さ との関倸を求めると Fig. 8 のごとくなる。

すなわち一般の $R_{p}=A I^{n}$ の関倸が成立する ${ }^{3)}$ 。

ただし $A$ はモノマー泱度, 增感剤浱度一定のときは 定数。

したがって

$$
R_{p}=A \times\left(I_{0} \times \frac{1}{10} \alpha \cdot c \cdot d\right)^{n}
$$

(3) 式を変形して

$$
\log R_{p}=\log A I_{0}{ }^{n}-n \cdot \alpha \cdot c \cdot d
$$

すなわち重合速度の対数と $d$ との間には直線関係が なりたち, Fig. 8 に示すごとく， $\left(3^{\prime}\right)$ に良く適合する。 この図における傾斜は $\left(3^{\prime}\right)$ 式の $(\alpha \cdot c \cdot n)$ に相応する。 今 (1) 式および (2) 式より $(\alpha)$ および $(n)$ の值と, 用 いた増感剤濃度 $(C)$ の積 $(\alpha \cdot c \cdot n)$ と, この Fig. 8 より 算出される傾斜 $(\alpha \cdot c \cdot n)$ とを Table 2 に示す。

$\alpha$ の単位を勝手な単位でとってあるので, $(\alpha \cdot c \cdot n)$ と Fig. 8 の直線の傾斜より得られる值 (Table 2. 6 行目) のオーダーは異なるが, その大小関倸は大体同じ傾向を

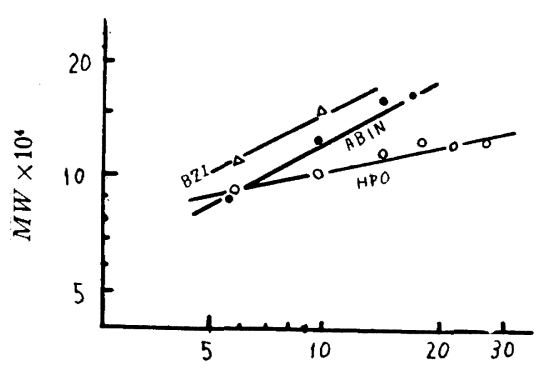

Thickness of cell $(\mathrm{cm})$

Fig. 9. Molecular weight vs. thickness of cell.

示し,この值の小さい方がセルの厚みが増しても重合速 度の均一性が得られることを示している。

同様なことは分子量についてもいえる。すなわち Fig. 9 に示すごとくであり，次式で導き出されるごとく $(\alpha$. $c \cdot n)$ の值の小さい方が均一な分子量の分布を示すこと になる。

すなわち一般に次式がなりたつ

$$
\frac{1}{P}-C_{I} \frac{[I]}{[M]}=C_{m}+C_{s} \frac{[S]}{[M]}+\frac{k_{t}}{k_{p}^{2}} \cdot \frac{R_{p}}{[M]^{2}}
$$

$C_{I} C_{m} C_{s}$ : 触媒, モノマー, 溶媒への連鎖移動定数

$[I][M][S]$ : 触媒, モノマーおよび溶媒の濃度

$k_{\ell} k_{p}$ ：停止および生成の速度定数

ここで $C_{I}$ がほとんど無視でき,かつ $[I][M][S]$ が一定 なら

$$
\frac{1}{P} \propto R_{p}
$$

(5) 式がなりたつ。

一方 $\left(3^{\prime}\right)$ 式を (5) 式に代入し, 変形すると（6) 式にな る。

$$
\log \frac{1}{P} \propto \alpha \cdot c \cdot d \cdot n
$$

Fig. 9 はこの式が適合することを示し, $(a \cdot c \cdot n)$ の小 さいHPO の場合に, 分子量がセルの厚さに対して均一 性を保ちやすいことが理解される。

$2.6 \mathrm{ZnCl}_{2}$ 湴度の重合速度に及ぼす影敏について 光重合でも熱重合でも，一般に塩化亜鉛水溶液中での AN の重合は水中や DMF などの溶媒中におけるより

Table 2. Relationships between the product of $(\alpha \cdot c \cdot n)$ and sensitizers.

\begin{tabular}{l|c|c|c|c|c}
\hline \hline Sensitizer & $\alpha$ & $n$ & $c(\mathrm{~mol} / l)$ & $\alpha \cdot n \cdot c \times 10^{-5}$ & $\begin{array}{c}\text { Calculated from the } \\
\text { slope of curve } \\
\text { in Fig. 8 }\end{array}$ \\
\hline HPO & 1 & 0.7 & $11.78 \times 10^{-4}$ & 0.825 & 0.77 \\
ABIN & 7.8 & 0.5 & $5.44 \times 10^{-4}$ & 1.685 & 2.25 \\
BZI & 12.5 & 0.5 & $3.30 \times 10^{-4}$ & 1.650 & 3.78 \\
\hline
\end{tabular}


もその速度は速く，かつ Modifier を添加しない場合に は分子量も高いといら非常に興味ある現象を示してい る。この $\mathrm{ZnCl}_{2}$ が重合に関与していることについては すでに, 宮道, 妹尾, 鈴木") が次の結果を得ている。

$\mathrm{ABIN}: R_{p}=k[\mathrm{AN}]^{1 \cdot 7}[\mathrm{ABIN}]^{0.5} \cdot\left[\mathrm{ZnCl}_{2}\right]^{-1}$

過硫酸力リ: $R_{p}=k[\mathrm{AN}]^{1.7}\left(\alpha+[\mathrm{KPS}]^{0.1}\right)\left[\mathrm{ZnCl}_{2}\right]^{2.8}$ 著者らも $40^{\circ} \mathrm{C}$ の光重合の場合に APS および $\mathrm{HPO}$ を 使用して重合を行ない， $\mathrm{ZnCl}_{2}$ 莀度を $55,57,60 ， 65$, 69 重量\%と変化しそれぞれの中で重合を行なった結果 を Fig. 10 に示す（ただし APSの場合のみを例示し た)。光源としてマッダ超高圧水銀灯 (SHL-100 UV) を 使用し, 光源より $4.5 \mathrm{~cm}$ の位直における重合率をプロ ットした。この場合, AN の薯度は $10 \mathrm{wt} \%$, APS は $0.3 \%$ (対モノマー)で行なった。これより速度定数を算 出し, $\mathrm{ZnCl}_{2}$ 浱度との関係をプロットすると Fig. 11 の ごとくなる。これより速度定数と $\mathrm{ZnCl}_{2}$ 漫度の関係を 算出し, かつ前報で述べたモノマー濃度および増感鼡と の関係を代入すると次式のようになる。

$$
\left.\begin{array}{ll}
\text { APS : } & R_{p}=k[\mathrm{AN}]^{1}\left(\alpha^{\prime}+[\mathrm{APS}]^{0.5}\right)\left[\mathrm{ZnCl}_{2}\right]^{2.50} \\
\mathrm{HPO}: & R_{p}=k[\mathrm{AN}]^{1}\left(\beta^{\prime}+[\mathrm{HPO}]^{0.4}\right)\left[\mathrm{ZnCl}_{2}\right]^{2.80}
\end{array}\right\}
$$

HPO の場合も同様にして算出した。

ここで $\alpha^{\prime}$ および $\beta^{\prime}$ は定数である。

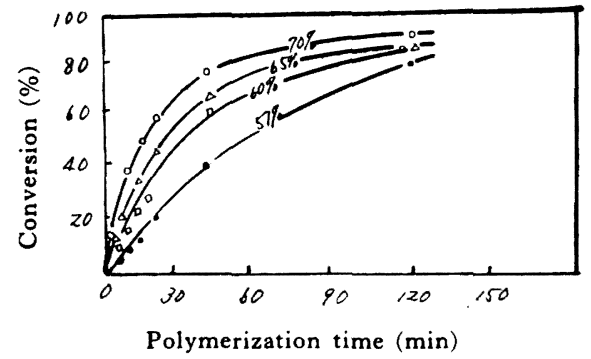

AN : $10 \mathrm{wt} \%$

APS : $0.3 w t \% /$ monomer

Temperature : $40^{\circ} \mathrm{C}$

Fig. 10. Dependence of polymerization rate on concentration of zinc chloride.

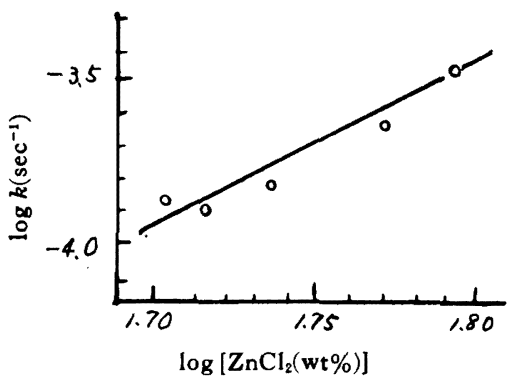

Fig. 11. Velocity constant vs. concentration of $\mathrm{ZnCl}_{2}$.

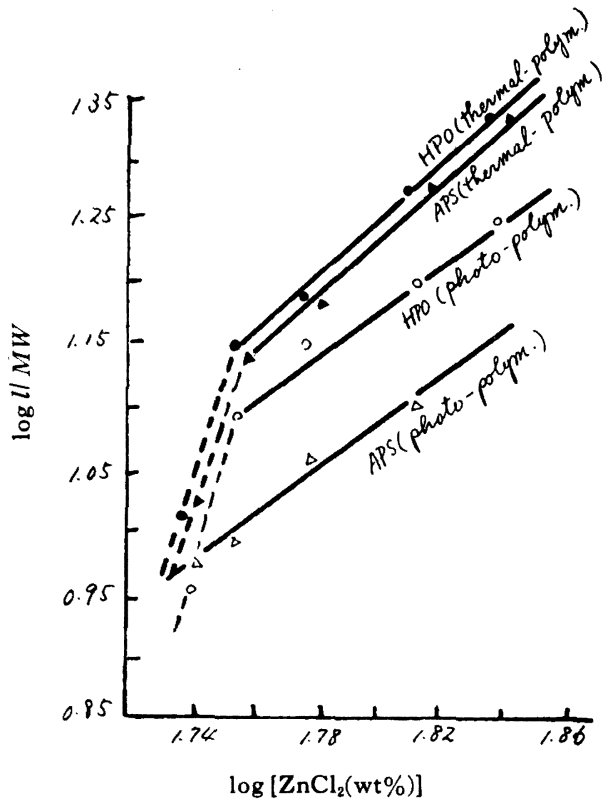

Fig. 12. Molecular weight vs. concentration of $\mathrm{ZnCl}_{2}$.

これより分子ごとく重合速度は $\mathrm{ZnCl}_{2}$ 浱度の $2.3 \sim 2.5$ 乗に比例していることがわかり宮道らの結果とほぼ一致 する。

次に $\mathrm{ZnCl}_{2}$ 濃度が分子量に与える影響を吟味してみ よう。前揭の (4) 式において $[M][S][I]$ が一定で, か つ $C_{S}$ が $\mathrm{ZnCl}_{2}$ 浱度によって影響されないとすると(8) 式で表わしうる。

$$
\frac{1}{P}=A^{\prime}+B R_{p}
$$

ただ $A^{\prime}=C_{m}+C_{I}([I] /[M])+C_{S}([S] /[M])=$ const, $B=k_{t} / k_{p}{ }^{2} \cdot 1 /[M]^{2}=$ const (7) 式より $R_{p} \propto\left[\mathrm{ZnCl}_{2}\right]^{m}$ で表 わしうるゆえこれを(8) 式に代入して変形すると，次式 で表わしらる。

$$
\log \frac{1}{P}=C+B^{\prime} \log \left[\mathrm{ZnCl}_{2}\right]
$$

ただし $C, B^{\prime}$ は定数である。

著者らの得た実験結果を Fig 12 に示す。 $55 \% \mathrm{ZnCl}_{2}$ 濃度の場合はややこの関係からはずれるが，これは臨界 濃度（均一溶液重合に対する最低 $\mathrm{ZnCl}_{2}$ 惯度）のためで あろらと考えられる。それ以上の濃度では (9) 式を满足 し，かつこれより計算すると，分子量の逆数は $\mathrm{ZnCl}_{2}$ 濃 度の $2.0 \sim 2.1$ 乗に比例する結果を得た。

\section{3. 考察}

通常光重合においての停止反応を考察すると次のごと 
く 3 通りの場合が考えられる。

$$
\left.\begin{array}{ll}
M_{n} \cdot+M_{m} \cdot \stackrel{k_{t}}{\longrightarrow} \text { inactive 反応 } \mathrm{A} \\
M_{n} \cdot+M & \stackrel{k_{t}}{\longrightarrow} \\
M_{n} \cdot & \stackrel{k_{t}}{\longrightarrow}
\end{array}\right\} \text { inactive } \text { 反応 } \mathrm{B}
$$

反応 A による停止の場合の重合速度は

$$
R_{A}=k_{p} \frac{f^{\frac{1}{2}}}{k_{t^{\frac{1}{2}}}}[M] I^{\frac{1}{2}}
$$

$I:$ 光強度 $f:$ 連鎖開始の量子収率

反応 B による停止の場合の重合速度は

$$
R_{B}=k_{p} \frac{f}{k_{t}}[M] I
$$

すなわち反応 A は, 光の強度の $1 / 2$ 乗に比例し,反応 B は光の強度の 1 乗に比例する。

一般に重合速度は $R_{p} \propto I^{n}$ で表わされ， $n$ は 1 と 0.5 の間にありその間の值をとる場合は，反応 $\mathrm{A}$ と反応 $\mathrm{B}$ とが混合していると解积する。反応 $\mathrm{A}$ 抢よび反応 $\mathrm{B}$

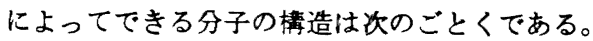

停止反応 A (触媒切片を Q とする) による場合<smiles>[C-]C(C#N)C=O</smiles>

停止反応 B による場合

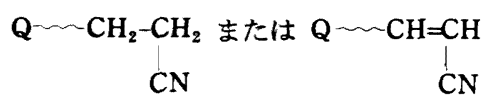

(1) 式の結果から ABIN, APS の場合は主として反応 A のことくラジカル同志の combination により停止し, HPO の場合は反応 A と反応 B (disproportionation) と が混合していると解釉すべきである。

次に (2) 式の結果について考察するに, 吸光係数の大 なるものほど透過光の强度低下は大きく，したがってか かる増感剤を使用したときはセルの厚さが増すに従い， 重合速度の低下が大きい。かかる意味において $\mathrm{H}_{2} \mathrm{O}_{2}$ は 吸光係数も低くまたその分解物も水と酸素のため, 紡釆 原液中に不良な不純物として混在する危険が少なく， 工業的に有用な増感剤である。また $\left(3^{\prime}\right)$ 式および (6) 式 から $(\alpha \cdot c \cdot n)$ の值の小さい方がセルの厚み $(d)$ が增大 しても重合速度および分子量の変動が少ないことがわか る。Table 2 の結果から HPO を增感郕として使用寸る ことは均一性の面からも非常に良好な結果を得ることに なる。以上述べたごとく，重合速度および分子量の均一 性については被照射体溶液をまったくかきませない場合 の条件について吟味したのであって，これをかきまぜる 場合はもちろん均一な重合液になるがかきまぜる場合で
も $(\alpha \cdot c \cdot n)$ の積の小さいものの方が, 全体の平均重合速 度は速く，また均一性も良いことは明らかである。

次に $\mathrm{ZnCl}_{2}$ がなぜ重合速度に 影響するかを考察して みた。Alfrey-Price ら ${ }^{5)}$ は $\mathrm{Q}, e$-scheme なるものを提 起し, 速度定数および共重合のモノマー反応性比 $r_{1}$ お よび $r_{2}$ は次式で表わしらるとしている。

$$
\begin{aligned}
k & =P, Q \exp \left(-e^{2}\right) \\
r_{1} & =\frac{k_{11}}{k_{12}}=\left(\frac{Q_{1}}{Q_{2}}\right) \exp \left[-e_{1}\left(e_{1}-e_{2}\right)\right] \\
r_{2} & =\frac{k_{22}}{k_{21}}=\left(\frac{Q_{2}}{Q_{1}}\right) \exp \left[-e_{1}\left(e_{2}-e_{1}\right)\right]
\end{aligned}
$$

ここで $Q$ : 共鳴安定性に関する項を表わし

$e:$ 極性項を表わす

したがって $e$ は反応系の誘電率の関数であり，溶媒の 誘電率により異なってくる。しかし実際には Lewis, Walling ${ }^{6)}$ はスチレンとメタクリル酸メチルとの共重合 においてメタノール $(D=33.7)$ ベンゼン $(D=2.28)$ ア セトニトリル $(D=33.8)$ 中で重合を行なった場合，そ の反応性比は変わらず,一定であったと述へているが, もし Alfrey-Price らの考え方が正しいとするなら、こ れを単独重合の場合にも応用して，今アクリロニトリル のポリマーラジカルとモノマーが反応するに際し， Zn が CN 基に電子的に配位して $\mathrm{CN}$ 基の極性の力を変え ているとするなら $\mathrm{ZnCl}_{2}$ が重合速度に関与すると考え ることは不思議でない。なお APS などの分解は水中よ り多少速いが重合の活性化エネルギーなどはさして差が ないことを確かめた。

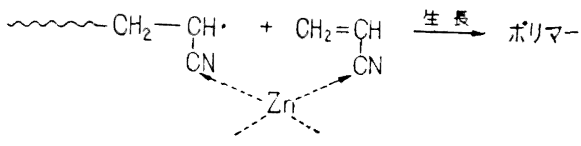

4. 結 語

$\mathrm{ZnCl}_{2}$ 水溶液中での $\mathrm{AN}$ の光重合は容易に進行し, $\mathrm{ZnCl}_{2}$ が重合に関与していることが明らかになった。

増感剂としては $\mathrm{ABIN}, \mathrm{BZI}, \mathrm{UO}_{2}\left(\mathrm{NO}_{3}\right)_{2}, \mathrm{HPO}, \mathrm{APS}$ がそれぞれ有効だが，重合速度，分子量の均一性に影響 を与える吸光倸数, Intensity exponent を考慮し,また 生成液の透明性を考虑すると $\mathrm{H}_{2} \mathrm{O}_{2}$ が紡系原液製造の增 感剤として使用する場合が最適である。

付 記：本研究の発表を許可された会社当局に感铌する。

$$
\text { 文献 }
$$

1) 吉田正俊, 谷山雅一：高化, 19,627 (1962)

2) C. A. Parker: Proc. Roy. Soc., 220, 140 (1953)

3) 本山卓彦：高分子展望第 14 集, 70(1959)

4）宮道一夫，妹尾忠雄，鈴木 亮：第 9 回高分子年 次大会 (大阪), (1960) 
5) P. Alfrey, C. C. Price: J. Polymer Sci., 2, 101 (1947)
6) F. M. Lewis, C. Walling: J. Am. Chem. Soc., 70, 1519(1948)

\section{Photo-polymerization of Acrylonitrile in Zinc Chloride Aqueous Solution.}

\section{Study of Sensitizers for the Photo-polymerization Induced by Ultra-violet Light}

\section{By Masatoshi Yoshida* and Masakazu Taniyama*}

Photo-polymerization of acrylonitrile in aqueous zinc chloride solution has been studied and the following results were obtained.

1) The relationship between the photo-rate $(R p)$ and the light intensity (I) were observed as

and

$$
\begin{aligned}
& R p \propto \mathrm{I}^{0.5} \text { for } \alpha \alpha^{\prime} \text {-azobisisobutylonitrile (ABIN) } \\
& R p \propto \mathrm{I}^{0.5} \text { for ammonium persulfate (APS) }
\end{aligned}
$$

$$
R p \propto \mathrm{I}^{0.7} \text { for hydrogen peroxide (HPO) }
$$

2) The ratio of absorption coefficient of ABIN and benzoin (BZI) to that of HPO were estimated as 7.82 and 12.5 respectively. In our experimental conditions, the observed photo-rate was expressed as

$$
\log R p=A^{\prime}-\alpha \cdot c \cdot n \cdot d \cdot
$$

where $\alpha$ is the absorption coefficient, $c$ the sensitizer concentration, $d$ the length of light path and $n$ the intensity exponent of photo-rate. $A^{\prime}$ represents a constant (at a given monomer concentration), so that when the magnitude of $(\alpha \cdot c \cdot n)$ is considerably smaller than that of $A^{\prime}$, the lowering of photo-rate along the light path will be small even at a distance far from the incident surface of light. The observed values of $(\alpha \cdot c \cdot n)$ are 0.77 for HPO, 2.25 for ABIN and 3.78 for BZI. Photo-polymerization with HPO was found to show the best homogeneity in both the photo-rate and the molecular weight of polyacrylonitrile produced along the light path.

3) Photo-rate depended on the concentration of zinc chloride in the reaction medium and their relationship was shown by

and

$$
R p=k[\mathrm{AN}]\left(\alpha^{\prime}+[\mathrm{AFS}]^{0.5}\right)\left[\mathrm{ZnCl}_{2}\right]^{2.50} \text { for APS }
$$

$$
R p=k[\mathrm{AN}]\left(\beta^{\prime}+[\mathrm{HPO}]^{0.5}\right)\left[\mathrm{ZnCl}_{2}\right]^{2.80} \text { for HPO }
$$

where $\alpha^{\prime}$ and $\beta^{\prime}$ represent constants.

Also, reciprocal of the molecular weight of the polymer produced was found to de proportional to the square of zinc chloride concentration. 